\title{
ПАРИЗЬКЕ ПРОГОЛОШЕННЯ ЮЛІАНА АВГУСТОМ (ЛЮТИЙ 360 р.)
}

У статті показано, щзо прийняття Юліаном титулу Августа було вимушеним. Встановлено, щзо изезар Юліан пробував розв'язати проблему дипломатичним шляхом і намагався уникнути громадянської війни у Римській імперії. Розкрито, щзо популярність Юліана і значні успіхи у відновленні провіниії активізували протест армії проти відправлення значної частини військ імператору Констанцію II. Доведено, щзо Юліан не відхилявся від виконання наказу і визнавав владу імператора над собою.

Ключові слова: імператор Констанцій II, цеезар Юліан, Галлія, Персія, Римська імперія, Август, паризьке проголошення.

תim. 7.

Mariia MARKOVYCH, PhD Student of Historical Department Drohobych Ivan Franko State Pedagogical University (Ukraine,Drohobych) markovych.mariia@yandex.ru

\section{PROCLAMATION OF JULIAN AS AUGUSTUS IN PARIS (FEBRUARY, AD 360)}

Constantius II gave the orders to Gallic troops to be sent to the East. Notarius Decentius arrived in Gaul with these orders. According to Constantius II's decision substantial numbers of Gallic troops were sent from Gaul to the East. Caesar Julian hesitated over decision because of the absence of the high command.

Julian organized accelerating sending of troops. Discontent with sending to foreign lands had grown in the army. It was peace in Gaul after numerous victories and soldiers didn 't want to leave the province.

Sintula obeyed emperor Constantius II's order and went to the east of the empire with one part of the army. The rest of the army went via Paris. Soldiers heard the appeal of Caesar at the outskirts of Paris. Julian protested against Constantius II's decision. He had enlisted a lot of barbarians on condition that they would never leave the territory of the province. The army did not want to fight against Persia. As a result it was a riot in the army. Soldiers acclaimed Julian their Augustus. He eventually consented to their demands after several refusals. Julian had power over the military command and soldiers after successful campaigns in Gaul.

The negotiations continued throughout 360 without any results. Two cousins could not share the power. Julian found out that the emperor bribed barbarian king Vadomarius to attack his troops. He used this tactics in fighting with the previous usurpers, Magnentius and Silvanius. A civil war had become inevitable. Julian with the army of 23,000 soldiers decided to march against the emperor. He divided his troops between his generals Nevitta and Jovinus. This division of the army intended to show the emperor larger forces of Caesar than they actually were. Julian arrived in Naissus by October of 361. There he wrote and sent letters to the local councils of Rome, Athens, Corinth and Sparta. One of these letters was preserved. It was a letter to the Athenians. He wrote this letters in defence of his conduct and now we are able to estimate Caesar Julian 's motives of activities.

The majority of researchers believe that this Paris proclamation was the late Roman usurpation. However, Julian's letter to the Athenians shows that he rejected the title of Augustus and the Paris proclamation was a spontaneous act of the troops. Julian was faced with a difficult choice. On the one hand he had to execute the order of the Emperor and send troops to the East and on the other hand the province of Gaul were threatened by the attack of the barbarians.

The article shows that the adoption of the title of Augustus by Julian was forced. It is established that Caesar Julian was tried to solve the problem diplomatically and attempted to avoid a civil war in the Roman Empire. The Julian's popularity and considerable success in province restoring intensified protest of the army against sending substantial part of troops to Constantius II are described. The author also proves that Julian has not deviated from the execution of the order and recognized the authority of the emperor over him. 
Key words: Emperor Constantius II, Caesar Julian, Gaul, Persia, the Roman Empire, Augustus, the Paris proclamation.

Ref. 7.

Мария МАРКОВИЧ,

аспирант кафедры всемирной истории Дрогобычского государственного педагогического университета имени Ивана Франко (Украина, Дрогобыч) markovych.mariia@yandex.uа

\section{ПАРИЖСКОЕ ПРОВОЗГЛАШЕНИЕ ЮЛИАНА АВГУСТОМ (ФЕВРАЛЬ 360 г.)}

В статье показано, что принятие Юлианом титула Августа было вынужденным. Установлено, что иеезарь Юлиан пытался решить проблему дипломатическим путем и избежать гражданской войнь в Римской империи. Раскрыто, что популярность Юлиана и значительныле успехи в восстановлении провинции активизировали протест армии против отправки большого числа войск императору Констанцию II. Доказано, что Юлиан не уклонялся от выполнения приказа и признавал власть императора над собой.

Ключевые слова: император Констанций II, цезарь Юлиан, Галлия, Персия, Римская империя, Август, парижское провозглашение.

Лит. 7.

Постановка проблеми. 3355 до 361 р. Римською імперією управляли два співправителі імператор Констанцій II і цезар Юліан, який був військовим намісником імператора у Галлії. До 360 р. сильно загострилася ситуація на сході імперії. Перси тривожили кордони Римської імперії постійними набігами. Імператор видав наказ, згідно з яким Юліан мав відправити йому всі свої найкращі війська. Виконання такого розпорядження означало залишити провінцію без армії в час, коли існували ще загрози нападів германських і франкських племен.

Аналіз останніх досліджень і публікацій засвідчує, що у сучасній історіографії приділена увага паризькому проголошенню Юліана Августом. Р. Еррінгтон вважає, що причиною цього послужило незадоволення армії повноваженнями Юліана як цезаря $[3,17]$. Р. Блоклі стверджує, що Юліан був свого роду військовим помічником імператора, який не мав, чітко визначених повноважень і залежав від волі Августа $[2,452]$. Дж. Негрі переконаний у тому, що якби Юліан відіслав свою армію імператору, то був би приреченим. У нього не залишалося іншого вибору, крім повстання проти наказу Констанція II [6, 84-85]. Розрив відносин з Констанцієм II відбувся не $з$ вини Юліана, а був наслідком розвитку подій на сході імперії, зазначає Т. Моммзен $[1,525]$.

Метою статті $є$ дослідити причини видання наказу про відкликання імператором військ, 3’ясувати, чи було паризьке проголошення спланованою узурпацією престолу Юліаном.

Виклад основного матеріалу. Юліан, завдяки проведеній успішній боротьбі проти варварів в Галлії, завоював собі велику повагу у війська. У той час на Сході сильно погіршилася ситуація. Шапур II - цар Персії (309 - 379) у 359 р. сильно активізував наступ проти Римської імперії [7, 212]. Допоміг йому у цьому перебіжчик Антонін - римський чиновник, який не зміг відкупитися від «боргової ями». Антонін збирав відомості про становище римської армії і передавав персам, брав участь у плануванні наступу на землі Римської імперії і був провідником перської армії (Amm. Marc. 18, 5, 1-8). Шапур II у супроводі Антоніна зумів добратися до міста Аміди, що розміщувалося на території сучасного міста Діярбакир в Туреччині, і захопити його, протримавши в облозі сімдесят три дні (Amm. Marc. 19, 8, 1-4). Для імператора Констанція II втрата цього міста була жахливою, оскільки він доклав багато зусиль до його розбудови, звів навколо нього оборонні стіни та вежі i, за повідомленням Амміана Марцелліна, хотів назвати його своїм іменем (Аmm. Marc. 18, 9, 1).

Стурбований такою ситуацією, імператор вирішив забрати від цезаря Юліана 3 Галлії частину війська для участі в бойових діях з персами на сході імперії. У лютому 360 р. нотарій Деценцій прибув до Галлії з наказом відправити значну кількість військ на схід імперії. Амміан називає й іншу причину, через яку імператор прийняв таке рішення, а саме: «... щоб слава Юліана не зросла ще більше...». Констанцій II відправив трибуна Деценція до цезаря і наказав йому 
негайно забрати допоміжні загони герулів, батавів, кельтів з петулантами і по триста чоловік 3 інших легіонів (Amm. Marc. 20, 4, 1-2). А це становило приблизно від третини до половини армії в Галлії $[4,56]$. Юліан стверджує, що це всі без винятку кращі війська (Jul. ad Ath. 282 d). Імператор дійшов висновку, що після налагодження ситуації в провінції, Юліану не потрібна наскільки чисельна армія [5, 51]. Повідомлення Амміана Марцелліна про те, що імператор віддав наказ завдяки намові Флоренція, пояснює ще одну версію причини відкликання військ імператором, окрім його стурбованості через перську загрозу.

У лютому 360 р. армія проголосила Юліана Августом в Парижі. Проте армія в Галлії не вперше пробувала здійснити такий переворот. Юліан був проголошений Августом ще після здобутої перемоги у битві при Аргентораті (357), але не прийняв тоді цей титул (Amm. Marc. $16,12,64)$. Дж. Негрі вважає, що він рішуче відмовився, оскільки обставини не були такими, які вимагали б здійснити вибір між бунтом і смертю $[6,85]$. Протягом зими $357-358$ рр. цезар активізував свою діяльність в адміністративній і цивільній сфері життя провінції. Юліан часто не погоджувався із рішеннями префекта преторія Флоренція щодо оподаткування. Імператор неодноразово закликав його підпорядкуватися префекту. Юліан не завжди підкорявся таким розпорядженням імператора і продовжував займатися адміністративною діяльністю, яка не входила до його повноважень. Він самостійно провів розрахунки податків і добився їх зменшення у провінції (Amm. Marc. 17, 3, 2-5). Коли Юліан зіткнувся з проблемою доставки харчів для армії з Британії по Рейну, то не погодився платити данину варварам, які контролювали ці території і всупереч рішенню префекта преторія і наказу імператора організував напад і підкорив ці племена, внаслідок чого забезпечив безкоштовну доставку провіанту (Jul. ad Ath. 279 d - 280 d). Можливо, Констанцій II з Флоренцієм вже тоді бачили в Юліановій ініціативі проведення адміністративної політики спробу узурпації. Костянтин наприкінці свого правління змінив Діоклетіанову концепцію цезаря. Двоє з його старших синів володіли, окрім військових, ще й деякими адміністративними повноваженнями, але не законодавчою владою. Констанцій II ще не був стурбований правонаступництвом, коли призначив співправителями Галла і Юліана, тому повернувся до цієї концепції, згідно з якою Юліан мав повноваження лише у військовій сфері життя провінції [2, 461].

У 358 р. цезар відзначився ще більшими успіхами у військових походах і активнішою діяльністю у цивільній сфері. Він діяв з власної ініціативи і протягом 359 р. здобув собі ще більшу популярність серед війська [2, 449]. Імператору про це неодноразово повідомляли (Amm. Marc. 20, 4, 1-2). А політика цезаря Юліана в Галлії підсилила протест армії проти відправлення Констанцію II значної іï частини.

До кінця 359 р., завдяки адміністративній політиці Юліана, в Галлії було зроблено більше, ніж просто стабілізовано ситуацію. І це дало йому досвід і освіту, гідну імператора. Юліан був в змозі зосередитися і вивчити військову кар'єру Юлія Цезаря і Марка Аврелія. Він зміг стати кращим солдатом у своїх військових навчаннях і тренуваннях. Дуже важливо відзначити, що своїм прикладом Юліан зумів завоювати лояльність та повагу своїх військ [5, 50-51].

Спочатку цезар підпорядкувався імператору і намагався виконати наказ про відправлення військ на схід імперії. Р. Блоклі стверджує, що Юліан був свого роду військовим помічником імператора, який мав делеговані, не визначені однак чітко повноваження і залежав від волі Августа. Та обставина, що наказ відправити допоміжні війська і загони по триста осіб з полків з Галлії на схід імперії був відданий не Юліану, а Лупіціну - магістру кінноти (magister militum), а також те, що Сінтулі - трибуну конюшні цезаря Юліана було наказано відібрати і доставити кращих серед скутаріїв і гентілів, підкреслює перевагу Констанція II і його авторитет над цезарем [2, 452]. Очевидно, що Юліан був зобов'язаний підпорядковуватися імператору $[4,56]$. Сінтула виконав наказ імператора і з вибраними кращими людьми зі скутаріїв та гентілів відправився до нього. На момент отримання наказу Лупіцін брав участь у британському поході, тому відправлення іншої частини армії було відкладено. Відсутність префекта преторія Флоренція сильно ускладнила прийняття рішення цезарем. Флоренцій перебував у В'єнні. Амміан Марцеллін пише, що він відлучився під приводом заготівлі харчів, щоб, насправді, бути подальше від заворушень в армії (Аmm. Marc. 20, 4, 6). Серед армії зростало невдоволення через такий наказ імператора, оскільки солдати 
не хотіли іти в чужі землі за Альпи тоді, коли в провінції після численних перемог був мир. Юліан робив усе для прискорення підготовки військ і їх відправки.

Юліан висловлював протести проти такого рішення імператора, тому що багато солдатів 3 варварів він завербував з умовою, що вони не будуть змушені йти за межі Галлії [5, 51]. Те, що Юліан поставився до наказу імператора $з$ недовірою, було повністю виправданим. Бачити необхідність розпоряджень у тому, щоб зробити Юліана як суперника безсилим, було цілком характерним для імператора. Число військ, якими володів цезар, не було великим, а Констанцій II хотів забрати від нього кращих перевірених ветеранів [1, 525].

Цезар вирішив виконати наказ і відправити війська. Зібрана армія мала пройти через Париж, де перебував Юліан. У передмісті він привітав свою армію і після цього запросив командирів на обід. Після обіду офіцери розійшлися по квартирах і вночі озброєна армія збунтувалася, оточила палац, де був імператор, і проголосила його Августом. Юліан довго не виходив з палацу, а вранку, коли вийшов, намагався заспокоїти армію тим, що він проведе переговори з імператором і переконає його відмовитися від цього наказу. Проте такі обіцянки цезаря армія не прийняла (Amm. Marc. 20, 4, 9-17), і солдати кидалися на нього з погрозами вбивства. Юліан пише, що погодився на їхні погрози, заспокоюючи себе усвідомленням того, що, якщо його вб'ють, хтось інший з радістю проголосить себе імператором. Він був піднятий на щиті, і на голову йому поклали ланцюжок, який імітував корону імператора (Amm. Marc. 20, 4, 18) (Jul. ad Ath. 284 d).

Після проголошення Юліана війська під командуванням Сінтули, які вирушили до імператора, повернулися назад до Парижа (Amm. Marc. 20, 5, 1). Наступного дня уже проголошений Август Галлії виступив перед армією з промовою, в якій вихваляв заслуги військ у походах проти варварів. Трохи згодом Юліан скористався можливістю, щоб винагородити своїх вірних прихильників і зробив нові призначення серед командування армії, не враховуючи ті, які робив раніше імператор $[4,58]$ (Amm. Marc. 20, 9,8; 21, 1,4). Префект преторія Флоренцій після всіх подій втік до імператора (Amm. Мarc. 20, 8, 21).

Християнські історики подають кардинально протилежну картину паризького проголошення Юліана Августом. Ермій Созомен причиною проголошення визначає авторитет цезаря у війську, проте замовчує про проведення Юліаном дипломатичних переговорів і наявність будь-якого листування з Констанцієм II. Він стверджує, що Юліан ніяк не пояснював ситуацію Констанцію II, а лише змінив командування в армії і виступив походом проти імператора (Soz. Hist. Eccl, V, 1). Сократ Схоластик також вказує на відсутність будь-яких дипломатичних спроб налагодження відносин між імператором і цезарем. Автор підкреслює активні спроби Юліана розпочати військовий конфлікт, зокрема, розповсюдження змісту листа Констанція II до варварів. За свідченнями Сократа Схоластика, Юліан виступає ініціатором громадянської війни (Socr. HE, III, 1).

Юліан знав, що кращим результатом для нього буде укласти угоду з імператором, коли Констанцій II має справу з перською загрозою на сході імперії. Юліан прагнув миру зі своїм двоюрідним братом, з надією, що відбудеться розподіл імператорської влади $[5,52]$. Причиною обурення військ проти виконання наказу імператора було те, що солдати після численних перемог не отримували ніяких винагород, а також те, що солдатам був звичний холодний клімат, і вони не хотіли відправлятися на війну в Персію. Юліан також повідомляє про скрутне становище в Галлії, спричинене набігами германських племен і відзначає, що провінція сама потребує допомоги ззовні (Amm. Marc. 20, 8, 16) і не в змозі відсилати військові загони. В листі до імператора Констанція II Юліан іменує себе Августом і пропонує дипломатичний шлях розв'язання цієї проблеми. Він полягав у компромісі між двома Августами. Юліан зобов'язувався надавати імператору упряжних коней з Іспанії і відсилати молодих летів (варвари, які отримали дозвіл на поселення в Римській імперії) із варварів. За імператором він хотів залишити право призначати префектів преторія, а сам хотів призначати решту чиновників і офіцерів в армії, а також власну свиту (Amm. Marc. 20, 8, 13-14). Якби Юліан відмовився від титулу Августа, то він, враховуючи характер імператора, підписав би собі смертний вирок $[1,526]$.

Імператор Констанцій II не прийняв пропозиції Юліана і не визнав його Августом. Він відправив послів з листом, в якому засуджував переворот у Парижі. Зразу після цих подій Констанцій II зробив деякі призначення у Галлії, незважаючи на думку Юліана (Amm. Marc. 20, 9, 4-8). 
Успіх Юліана проти варварських племен у Галлії міг би бути лише тимчасовим, якби імператору вдалося забрати досвідчених ветеранів і відправити на східний фронт. Переговори протягом 360 р. були безрезультатними. Юліан дізнався, що імператор підкупив племена варварів, щоб атакувати його військо. Імператор тут використовував таку ж тактику боротьби, як проти узурпаторів Магненція і Сільвана [5, 53].

Юліан влаштував святкування п’ятиріччя свого правління у В’єнні у 361 p. (Amm. Marc. 21, $2,4)$. Така провокаційна демонстрація Юліана, як Августа Галлії сигналізувала про кінець безвихідного положення дипломатичних відносин з Констанцієм II. Юліан захопив у полон алеманського короля Вадомарія, який підтвердив, що його атаки були ініційовані Констанцієм II (Amm. Marc. 21, 3, 5). Він кинув відкритий виклик імператору арештом Вадомарія (Amm. Marc. 21, 4, 5-8). Юліан звинуватив Констанція II у заохоченні Вадомарія нападати на кордони провінції, на підставі листування між ними (Jul. ad Ath. 287 a). Констанцій II готувався до громадянської війни. Вадомарій своїми нападами мав послабити сили Юліана в Галлії. I виявлення цього Юліаном стало приводом до походу проти імператора. Громадянська війна стала неминучою (Amm. Мarc. $21,5,13)[5,53-54 ; 4,58-59]$.

Юліан з 23-х тисячним військом вирушив проти імператора. Війська були розділені під командуванням двох генералів Іовіана та Невітти. Іовіан мав пройти в Італію, Невітта відправився дорогою через Рецію, а сам Юліан - через Шварцвальд. Це було зроблено, щоб справити сильніше враження на імператора про кількість армії (Amm. Marc. 21, 8).

У місті Ниш (Naissus) Юліан написав і відправив листи з поясненням своїх дій, адресовані у різні міста Греції: Афіни, Коринф і Спарту, а також звернення до сенаторів у Рим. Останні були обурені неповагою Юліана до імператора (Amm. Marc. 21, 10, 7) [4, 60]. 3 цих листів до нас дійшов лише один - звернення до афінян. Про паризьке проголошення Юліана Августом нам повідомляють і язичницькі автори, серед яких: Амміан Марцеллін, Лібаній і Зосім. Проте свідчення самого Юліана також є цінними. Т. Моммзен вважає Юліана правдивим оповідачем, оскільки його повідомлення підтверджуються фактами [1, 525].

На думку Т. Моммзена, імперія насправді не була єдиною. Тільки завдяки випадковості і війні проти узурпатора Магненція Констанцію II вдалося об'єднати дві внутрішньо розділені і вже відчужені одна від одної половини імперії. Солдати і народ західної частини імперії знову хотіли окремого правителя [1, 524].

Після проголошення Юліана Августом в Парижі він ще намагався знайти порозуміння з Констанцієм ІІ. Оскільки така спроба потерпіла поразку, Юліан вирішив іти війною з Галлії проти імператора. Він уважав, що залишатися в Галлії небезпечно, тому що Констанцій II може напасти на нього зі всіх сторін - 3 тилу і флангів силами варварів, а зі своїми легіонами - 3 фронту. Для нього було ганебно виявитися слабшим через страх і нерозуміння, аніж через множинність сил імператора Констанція II. Юліан пише, що повинен був заручитися підтримкою наймогутніших племен і грошовим забезпеченням, відчеканивши золоту і срібну монети, щоб прибути з тим, чим володіє у випадку, якщо імператор відмовиться з ним воювати (Jul. ad Ath. $286 \mathrm{~d}-287$ c).

Армія в Галлії під командуванням Юліана здобувала перемогу за перемогою. Як Юліан, так і армія були незадоволені званням цезаря і на церемонії в Парижі він заявив про свою рівність з Констанцієм II. Юліан став Августом [3, 17]. На думку Д. Ханта, процедура проголошення Юліана Августом в Парижі показує деякі складові пізньоримської узурпації. Такими складовими $\epsilon$ - розпалення невдоволення, зібрання військ, вечеря з військовим командуванням, Юліан в імператорському вбранні. Юліан посилається на «волю богів», аби приховати свою відповідальність за те, що сталося. Проте такі дії Юліана були спровоковані ситуацією, яка склалася в Галлії. Констанцій сам підштовхнув його до повстання тим, що хотів забрати найкращі війська від цезаря $\mathrm{i}$ підкуповував племена алеманів, які мали спустошувати провінцію. Спроби переговорів закінчилися дипломатичними докорами з боку імператора Констанція II [4, 57-58].

3 листопада 361 р. під час походу проти Юліана помер імператор Констанцій II, в місті Мопсукрена поблизу Тарсу, залишивши наступником свого двоюрідного брата Юліана (Атm. Marc. 21, 15, 1-3). Перед смертю Констанцій II продемонстрував державну і династичну солідарність, підтверджуючи неминуче і публічне визнання Юліана Августом [3, 18]. 11 грудня Юліан 
з узурпатора перетворився на одноосібного правителя Римської імперії. Якби справа дійшла до війни, то результат міг виявитися досить сумнівним, оскільки Італія була на стороні Констанція II і закрила перед Юліаном двері $[1,527]$.

Висновки. Отже, прийняття Юліаном титулу Августа було вимушеним. Призначаючи Юліана цезарем, Констанцій II обмежив його у повноваженнях. Юліан був військовим намісником імператора у Галлії, проте спочатку не був навіть головнокомандувачем військ у провінції. Керувати військами йому було дозволено аж з 357 р. А беручи до уваги те, що Юліан проводив й адміністративну політику, часто всупереч префекту преторія Флоренцію і імператору, що викликало обурення у двох останніх. Тому ми можемо стверджувати, що напади персів на сході імперії не були єдиною причиною відкликання військ із заходу імперії. А неодноразові спроби відмовитися від титулу Августа вказують на те, що Юліан не планував узурпувати владу в імперії.

\section{СПИСОК ВИКОРИСТАНИХ ДЖЕРЕЛ І ЛІТЕРАТУРИ}

1. Моммзен Т. История римских императоров / Т. Моммзен / [пер. Т. А. Орестовой]. - СПб.: Ювента, 2002. $-628 \mathrm{c}$.

2. Blockley R. C. Constantius Gallus and Julian as Caesars of Constantius II / R. C. Blockley // Latomus. 1972. - Fasc. 2. - T. 31. - P. 433-468.

3. Errington M. R. Roman imperial policy from Julian to Theodosius / M. R. Errington. - Chapel Hill: The University of North Carolina Press, 2006. XII+336 p.

4. Hunt D. Julian / D. Hunt // CAH ${ }^{2}$. - Cambridge: Cambridge University Press, 1998. - Vol. XIII. - P. 44-77.

5. Marshall L. Companison to the Gods, Friend to the Empire: the Experiences and Education of the Emperor Julian and How It Influenced His Reign 361 - 363 Ad. Master of Arts (History) / L. Marshall. - August 2014. $108 \mathrm{p}$.

6. Negri G. Julian the Apostate. Translated from the second Italian edition by the Duchess Litta-Visconti-Arese / G. Negri. - New York: Scribner, 1905. - Vol. I. - XXXIV + 320 p.

7. Samuel N. C. Lieu and Dominic Montserrat (edd.), From Constantine to Julian: Pagan and Byzantine Views, A Source History / G. Negri. - London: Routledge, 1996. - XXI+285 p.

\section{REFERENCES}

1. Mommzen T. Istoriya rimskikh imperatorov / T. Mommzen / [per. T. A. Orestovoy]. - SPb.: Yuventa, 2002. $-628 \mathrm{c}$.

2. Blockley R. C. Constantius Gallus and Julian as Caesars of Constantius II / R. C. Blockley // Latomus. 1972. - Fasc. 2. - T. 31. - P. 433-468.

3. Errington M. R. Roman imperial policy from Julian to Theodosius / M. R. Errington. - Chapel Hill: The University of North Carolina Press, 2006. XII+336 p.

4. Hunt D. Julian / D. Hunt // CAH ${ }^{2}$. - Cambridge: Cambridge University Press, 1998. - Vol. XIII. - P. 44-77.

5. Marshall L. Companison to the Gods, Friend to the Empire: the Experiences and Education of the Emperor Julian and How It Influenced His Reign 361 - 363 Ad. Master of Arts (History) / L. Marshall. - August 2014. $108 \mathrm{p}$.

6. Negri G. Julian the Apostate. Translated from the second Italian edition by the Duchess Litta-Visconti-Arese / G. Negri. - New York: Scribner, 1905. - Vol. I. - XXXIV + 320 p.

7. Samuel N. C. Lieu and Dominic Montserrat (edd.), From Constantine to Julian: Pagan and Byzantine Views, A Source History / G. Negri. - London: Routledge, 1996. - XXI+285 p.

Стаття надійила до редакиії 31.03.2017 p. 